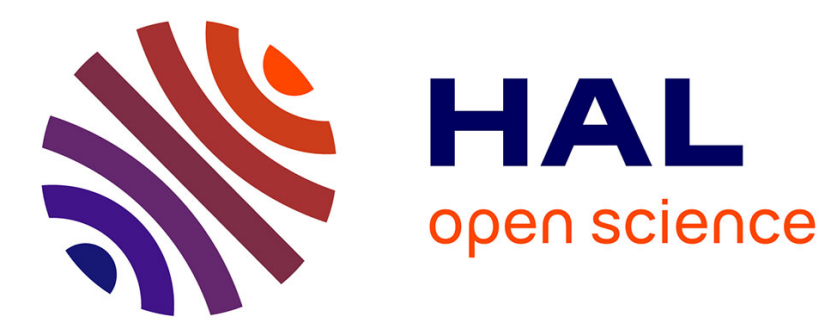

\title{
Light absorption and thermal measurements of black carbon in different regions of Canada
}

\author{
S. Sharma, J.R. Brook, H. Cachier, J. Chow, A. Gaudenzi, G. Lu
}

\section{To cite this version:}

S. Sharma, J.R. Brook, H. Cachier, J. Chow, A. Gaudenzi, et al.. Light absorption and thermal measurements of black carbon in different regions of Canada. Journal of Geophysical Research, 2002, 107 (D24), 10.1029/2002JD002496 . hal-03127243

\section{HAL Id: hal-03127243 \\ https://hal.science/hal-03127243}

Submitted on 9 Feb 2021

HAL is a multi-disciplinary open access archive for the deposit and dissemination of scientific research documents, whether they are published or not. The documents may come from teaching and research institutions in France or abroad, or from public or private research centers.
L'archive ouverte pluridisciplinaire HAL, est destinée au dépôt et à la diffusion de documents scientifiques de niveau recherche, publiés ou non, émanant des établissements d'enseignement et de recherche français ou étrangers, des laboratoires publics ou privés. 


\title{
Light absorption and thermal measurements of black carbon in different regions of Canada
}

\author{
S. Sharma, ${ }^{1}$ J. R. Brook, ${ }^{1}$ H. Cachier, ${ }^{2}$ J. Chow, ${ }^{3}$ A. Gaudenzi, ${ }^{1}$ and G. Lu ${ }^{1}$ \\ Received 30 April 2002; revised 14 August 2002; accepted 16 August 2002; published 20 December 2002.
}

[1] A study was conducted to determine the relationship between light absorption measurements from an aethalometer and a particle soot absorption photometer (PSAP) and black carbon mass concentrations across Canadian environments ranging from urban to remote areas. To achieve this, filter samples were collected for thermal analysis of black carbon simultaneously with light absorption measurements at several locations in Canada. Previously, it has been shown that the k relating particle light absorption to black carbon measured with an aethalometer changes with age, type, and composition of the aerosol, which varies with time and by space [Liousse et al., 1993; Petzold and Niessner, 1995; Lavanchy et al., 1999; Ruellan and Cachier, 2000]. Consequently, to convert light absorption measurements to the black carbon mass, the standard values used for $\mathrm{k}$ of $19 \mathrm{~m}^{2} \mathrm{~g}^{-1}$ for aethalometer and $10 \mathrm{~m}^{2} \mathrm{~g}^{-1}$ for PSAP, respectively, need to be fine-tuned to fit the conditions at the site of interest to obtain the site-specific attenuation, referred to as $\mathrm{k}(\mathrm{S} . \mathrm{S}$.). Our results also indicate that k(S.S.) varies; on a broad scale, from remote continental to rural, suburban, and urban locations and from winter to summer and, on a small scale, within an urban area and from measurement to measurement at a single location. The range of median $\mathrm{k}(\mathrm{S} . \mathrm{S})$ values observed was from $6.4 \mathrm{~m}^{2} \mathrm{~g}^{-1}$ to $20.1 \mathrm{~m}^{2} \mathrm{~g}^{-1}$. We suggest that the variability is connected to the distribution of sources and processes contributing to the carbonaceous aerosols at the sites. INDEX TERMS: 0305 Atmospheric Composition and Structure: Aerosols and particles (0345, 4801); 0345 Atmospheric Composition and Structure: Pollution — urban and regional (0305); 0394 Atmospheric Composition and Structure: Instruments and techniques; 0399 Atmospheric Composition and Structure: General or miscellaneous; KEYWORDS: carbonaceous aerosols, urban-rural-remote, black carbon, specific attenuation coefficient, optical measurements

Citation: Sharma, S., J. R. Brook, H. Cachier, J. Chow, A. Gaudenzi, and G. Lu, Light absorption and thermal measurements of black carbon in different regions of Canada, J. Geophys. Res., 107(D24), 4771, doi:10.1029/2002JD002496, 2002.

\section{Introduction}

[2] Carbonaceous aerosols are released in the atmosphere from incomplete combustion of fossil fuels and biomass. They are present in remote regions as a result of long-range transport from high-emission regions. As a result of their long atmospheric lifetime, the size, composition and mixing state of the carbonaceous aerosol changes when transported from source to receptor regions as other primary and secondary gases and organic compounds condense on them, possibly facilitating other reactions [Smith et al., 1989; De Santis and Allegrini, 1992]. Consequently, with time the aerosol is composed of at least two components: a dark component called black carbon or light absorbing carbon and another scattering component

\footnotetext{
${ }^{1}$ Meteorological Service of Canada, Toronto, Ontario, Canada.

${ }^{2}$ Centre des Faibles Radioactivités, Laboratoire des Sciences du Climat et de l'Environnement, Laboratoire Mixte, Commissariat à l'Energie Atomique, Centre National de la Recherche Scientifique, Gif sur Yvette, France.

${ }^{3}$ Desert Research Institute, Reno, Nevada, USA.
}

Copyright 2002 by the American Geophysical Union. 0148-0227/02/2002JD002496 (containing organic carbon and water soluble species such as sulfates).

[3] The black carbon, also known as the "greenhouse aerosol," affects the climate by absorbing solar energy, which in turn heats up the atmosphere [Andreae, 2001]. The magnitude of this direct effect may vary depending on how black carbon is mixed with other aerosol components. This heating has been illustrated by recent modeling results showing that the magnitude of the direct radiative forcing from the black carbon may be the second most important component of global warming after $\mathrm{CO}_{2}$ [Jacobson, 2001]. Thus, with such importance in the atmosphere, accurate determination of black carbon ambient mass concentrations and its atmospheric behavior including long-term trends and light absorbing characteristics is required so that it can be modeled properly and its consequences better understood.

[4] There are several published analytical techniques to determine aerosol black carbon concentration [Ballach et al., 2001; Birch and Cary, 1996; Cachier et al., 1989; Chen et al., 2001; Chow et al., 1993; Fung, 1990; Keeler, 1990; Tohno and Hitzenberger, 2000; Yu et al., 2002]. The predominant methods in use today utilize thermal techniques to release and detect total carbon. The black carbon 
Table 1. Logistics of the Field Operations for Sample Collection at All Sampling Sites

\begin{tabular}{lllll}
\hline \multicolumn{1}{c}{ Location } & \multicolumn{1}{c}{ Type } & \multicolumn{1}{c}{ Time Period } & Thermal Technique & Sample Collection Time \\
\hline Alert & Remote/continental & Nov 98 to July 1999 & 2-Step & 2 weeks \\
Egbert & Rural & July 18 to July 25, 1998 & TOR & $12 \mathrm{hr}$. \\
Downsview & Suburban & Jan 5 to Feb 11, 2000 & TOR & $24 \mathrm{hr}$. \\
Evans Avenue & Urban (besides highway) & Mar 14-29, 2000 & MSC1(TOT) & $12 \mathrm{hr}$. \\
Winchester Road & Urban (School yard) & Aug 11-19, 2000 & MSC1(TOT) & $12 \mathrm{hr}$. \\
Palmerston Road & Urban (school yard) & Aug 21-31, 2000 & MSC1(TOT) & $12 \mathrm{hr}$. \\
\hline
\end{tabular}

${ }^{\mathrm{a}} \mathrm{MSC} 1$ is TOT technique with temperature specification of MSC1.

(BC) fraction is then operationally defined and often interchangeably referred to as elemental carbon (EC). However, it is ambiguous as to whether $\mathrm{BC}$ and $\mathrm{EC}$ are the same or how they differ. An absolute measurement technique and a $\mathrm{BC}$ or EC standard remain elusive [Schmid et al., 2001] because of its complex characteristics and lack of a clear definition that is relevant to atmospheric aerosols. One reason for this and the ambiguous terminology is because the definition of $\mathrm{BC}$ or EC may vary depending upon which atmospheric issue is of concern. For example, light absorption characteristics are important for climate change and visibility while source and subsequent chemical composition, including attached organics and inorganics are important for human health. In this paper, we will use the term $\mathrm{BC}$, as it is more intuitively related to light absorption and composition. However, EC, which may more correctly describe what the thermal techniques measure, is related mainly to graphitic carbon content.

[5] Optical techniques based upon light absorption of atmospheric particles sampled on filters and Mie theory are also widely used to estimate concentrations. In general, this approach depends upon assumptions based either on theoretical considerations or comparison of absorption and analytically determined BC. Calibration of the optical techniques, such as the aethalometer [Hansen et al., 1984], is a well-recognized problem. While BC from the thermal technique can be used to determine this calibration factor, $\mathrm{k}$, which is sometimes referred to as specific attenuation coefficient, one should consider that variations in $\mathrm{k}$ may occur. This is primarily due to other particle-bound material accompanying $\mathrm{BC}$ but may also be due to factors such as relative humidity. Some of these factors can influence the measurements of both the optical and thermal techniques and lead to uncertainty in the value of $\mathrm{k}$, which is problematic, if the goal is to accurately determine the concentration of $\mathrm{BC}$. Conversely, variation in the value of $\mathrm{k}$ likely also contains information on particle chemical composition or the matrix containing BC. Unfortunately, it is difficult to fully separate this information from the uncertainties. For example, $\mathrm{BC}$ from the thermal technique is uncertain due to alkaline metals catalyzing the EC oxidation at lower temperatures, especially for samples rich in sodium and potassium [Novakov and Corrigan, 1995] or pyrolysis of organic compounds [Yu et al., 2002]. Some methodological problems in the optical technique stem from the enhancement of the light measurements by particles embedded in the fibrous filter matrix leading to multi-reflections and effects of the filter itself (scattering) [Liousse et al., 1993; Edwards et al., 1983]. This enhancement could be as much as a factor of 3 [Waggoner et al., 1981; Horvath, 1997]. Despite the limitations, both the thermal and optical techniques provide valuable information and are presently the best available.

[6] In order to gain a better understanding of a 10-year time series of optical black carbon measurements made by using an aethalometer at Alert, Nunavut, located in Canada, we compared measurements from two general approaches, direct light absorption measurements (optical instruments) on a filter [Hansen et al., 1984; Bond et al., 1999] and thermal determination methods such as the 2-step thermal method [Cachier et al., 1989] and Thermal Optical Reflectance, TOR [Chow et al., 1993, 2001] Total Optical Transmittance, TOT. Comparisons were made from measurements taken at remote, rural and urban locations. In addition to Alert, other Canadian sites were examined to determine the degree to which the factor linking thermal BC to the light absorption measurements varies by location and season. Such variation has been reported in previous studies [Liousse et al., 1993; Petzold and Niessner, 1995]. While it may be important to use a consistent factor for a given site, and perhaps season, when converting optical measurements to $\mathrm{BC}$ concentrations to avoid an additional source of variability and possibly uncertainty, it is also important to examine how the optical and thermal techniques relate. This information will help when comparing different data sets, including model-generated data. Furthermore, differences in their relationship are expected to reflect differences in aerosol composition/characteristics. In this paper, the optical and thermal $\mathrm{BC}$ approaches are compared using ambient measurements collected at six different Canadian sites to determine the calibration factor(s) for the $\mathrm{BC}$ data obtained from the optical instruments. Here we focus on the differences in the calibration factor or specific attenuation coefficient $\mathrm{k}$ (conversion factor relating the light absorption measurements to $\mathrm{BC}$ mass) among sites. We also discuss the differences in $\mathrm{BC}$ among sites, across time and as a function of wind speed and direction, taking advantage of the time resolution provided by aethalometer measurements.

\section{Measurement Program}

\subsection{Measurement Sites and Collection Periods}

[7] The study was conducted during different time periods as listed in Table 1. The quartz fiber filters collected for the thermal analysis were sampled over the averaging times shown in the table. The specific analytical techniques used, which are described below, are also listed.

[8] For the urban sites, wind speed and wind direction data was obtained from the met-station at the Pearson International airport in Toronto. The other sites had its own meteorological station collecting wind speed and wind direction data at $10 \mathrm{~m}$. 
[9] Alert is a remote continental site and located at $82^{\circ} 27^{\prime} \mathrm{N} 62^{\circ} 31^{\prime} \mathrm{W}$ on the edge of the Lincoln Sea at the northeastern tip of Ellesmere Island in the Canadian Arctic (Figure 1). The terrain in the immediate area is rolling and is $100-150 \mathrm{~m}$ above sea level with frequent deep ravines and high cliffs. The land is covered with snow 10 months of the year, however, during the summertime there is sparse polar desert vegetation. In addition to its remote location, what makes this region unique is the 106 days of total darkness, 153 days of $24 \mathrm{hr}$-sunlight and two 53 day transition periods. The arctic circulation influencing the site is controlled by semi-permanent pressure systems giving rise to an Arctic vortex, which can bring in air masses from as far as Asia and Europe during the winter. However, the site is influenced by an air mass of local origin during the summertime [Barrie and Platt, 1997; Worthy et al., 1999]. The samples included in this intercomparison, averaged over two week periods, were collected from November 1998 to July 1999 for the thermal analysis. Additional samples from August 1999 to September 2000 were also collected for thermal analysis and were used to determine summer (May-October) and winter (November-April) values of $\mathrm{k}$.

[10] Egbert is a rural site, located $75 \mathrm{~km}$ northwest of Toronto and is surrounded by farmland and vegetation. Thus, a mixture of background concentrations and biogenic emissions from the vegetation and anthropogenic emissions from the local population (sparse) and the neighboring urban regions $(25-75 \mathrm{~km}$ away) influence this site. Twelve-hour average samples were collected each day from July 17 to 25,1998 , for the thermal analysis.

[11] Downsview is influenced by nearby dense residential and commercial activities. This site is classified as a suburban site located on the rooftop of the Meteorological Service of Canada building, $30 \mathrm{~m}$ above the road-level. This site is also influenced by nearby traffic on the nearby major roads, which is heavy during rush hour. Twenty-four hour averaged samples were collected each day during January 10 to February 11, 2000 for the thermal analysis.

[12] Winchester and Palmerston Road sites are residential urban sites located in central Toronto. Both were situated in a schoolyard at least $200 \mathrm{~m}$ from the main roads. The sampling period for Winchester was from August 12 to 20 and for Palmerston from August 21 to 31, 2000. The last site, Evans Avenue, is $75 \mathrm{~m}$ south of a major highway that has consistently heavy automobile and diesel traffic and thus influenced by fresh vehicular emissions. This site is also influenced by mixed commercial, light industrial and residential sources in the area.

\subsection{Sample Collection}

[13] Filters for thermal analysis were collected in parallel with the optical measurements by using the same or identical sampling inlets except at Downsview where absorption measurements and thermal analysis were done on the same filter (i.e., the aethalometer filter was sent out for TOR analysis). The sampling inlets were approximately $10 \mathrm{~m}$ above the ground level at all sites except for Alert and Downsview where they were at the height of $20 \mathrm{~m}$ and $30 \mathrm{~m}$ above the ground, respectively. All inlets had cyclones with a size-cut of $2.5 \mu \mathrm{m}$ except for at Alert where there was no size cut. Constant mass flow controllers were used to

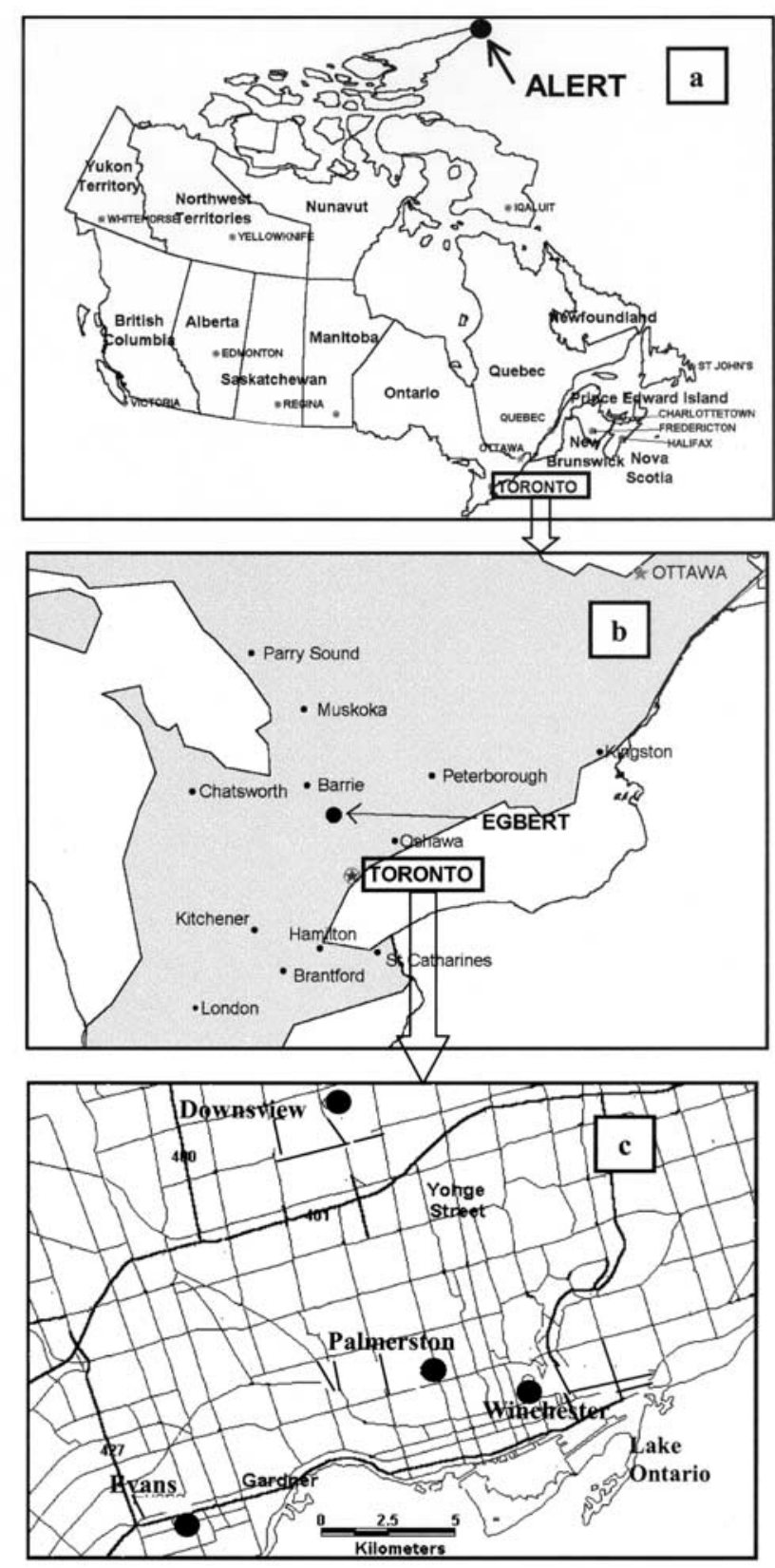

Figure 1. Six sampling locations in Canada (maps in Figures $1 \mathrm{~b}$ and $1 \mathrm{c}$ are the zoomed-in locations of the map in Figure 1a). Figure 1a shows Alert, a remote-continental site, Figure 1b shows Egbert (rural site) and Figure 1c shows urban sites such as Palmerston high school, Winchester high school and Evans Avenue and a suburban site Downsview.

maintain a sampling rate, through $47 \mathrm{~mm}$ quartz fiber filter, of 10 slpm twice a day at Palmerston and Winchester, 15 slpm at Evans and Egbert and at $30 \mathrm{slpm}$ at Alert. For the optical measurements, the samples were collected at a flow of $5 \mathrm{slpm}$ for the aethalometer and $1 \mathrm{slpm}$ for the PSAP.

[14] After each run, the filters were placed in a quartz filter sandwich and stored in a plastic petri-dish. For Alert, Downsview and Evans Ave., these petri-dishes were wrapped with pre-cleaned (heated) aluminum foil. After they were received from Alert and for the other sites they were 
kept cold $\left(<4^{\circ} \mathrm{C}\right)$ even during shipment, until the analysis was completed.

\subsection{Thermal Carbon Analysis}

\subsubsection{Two-Step Thermal Method}

[15] The details of this technique are given by Cachier et al. [1989]. Briefly, a decarbonation step in $\mathrm{HCl}$ fumes was applied to the sample filters prior to analysis. During the pre-combustion step organic material is removed from the filter under a flow of pure oxygen at $340^{\circ} \mathrm{C}$ for a period of 2 hours. In step 2 , the remaining carbon (black carbon) was determined by coulometeric titration (by using a Strohlein Coulomat $702 \mathrm{C}$ analyzer) of $\mathrm{CO}_{2}$ evolved from the combustion of the sample at $1100^{\circ} \mathrm{C}$. The samples were collected on Pallflex quartz filters (47 mm, 2500QAT-UP filters from Gelman Sciences). In order to achieve lower blank levels, the filters were preheated at $700^{\circ} \mathrm{C}$ for black carbon and $400^{\circ} \mathrm{C}$ for the total carbon. The organic carbon was determined by subtracting $\mathrm{BC}$ from $\mathrm{TC}$. The precision of this technique is better than $\pm 10 \%$ and the limit of detection is $3 \mu \mathrm{g} \mathrm{C}$. Filter samples from Alert were analyzed by using this method.

\subsubsection{Thermal Optical Reflectance Method (TOR)}

[16] This technique is based on the preferential volatilization and/or oxidation of organic compounds and elemental carbon at increasing temperatures. Details are given by Chow et al. [1993]. A quartz filter sample is heated in a stepwise fashion to temperatures of 120, 250, 450 and $550^{\circ} \mathrm{C}$ in a pure helium atmosphere for organic carbon determination. Then the sample is combusted at 550, 700 and $800^{\circ} \mathrm{C}$ in $2 \% \mathrm{O}_{2}$ in $98 \%$ Helium for elemental carbon determination. The carbon evolved at each step is converted to methane and detected by FID. Charring of the organics is also measured by laser beam reflectance during the analysis. This pyrolysis fraction is subtracted from the elemental fraction and added to the organic fraction. The technique has precision of $\pm 10 \%$ and a detection limit of $0.2 \mu \mathrm{g} \mathrm{C}$ per $\mathrm{cm}^{2}$. The TOR method, following the IMPROVE protocol, has been used to report four organic carbon fractions (OC1, $\mathrm{OC} 2, \mathrm{OC} 3, \mathrm{OC} 4)$, three elemental carbon fractions (EC1, EC2, EC3), and pyrolytic carbon (OP). In the TOR method, the residence time at a given temperature step is sufficient for each FID carbon peak to be well defined and is different for every sample. A change from one temperature set point to the next is not initiated until the slope of the FID response approaches zero.

\subsubsection{Thermal Optical Transmittance (MSC1)}

[17] BC concentrations for Evans Avenue, Winchester and Palmerston Public Schools were determined using a Sunset Labs Thermal Optical Transmission Instrument at the Meteorological Service of Canada. The temperature program utilized was a combination of the NIOSH 5040 [Birch and Cary, 1996] and TOR (DRI) methods allowing long enough dwell times at each temperature to separate $\mathrm{CH}_{4}$ peaks. A quartz filter sample is heated in a stepwise fashion to temperatures of $250^{\circ} \mathrm{C}$ for $150 \mathrm{~s}, 450^{\circ} \mathrm{C}$ for $150 \mathrm{~s}$, $550^{\circ} \mathrm{C}$ for $180 \mathrm{~s}$ and $900^{\circ} \mathrm{C}$ for $90 \mathrm{~s}$ in a pure helium atmosphere for organic carbon determination. The sample is then combusted at $550^{\circ} \mathrm{C}$ for $240 \mathrm{~s}, 700^{\circ} \mathrm{C}$ for $210 \mathrm{~s}$ and $800^{\circ} \mathrm{C}$ for $150 \mathrm{~s}$ in $10 \% \mathrm{O}_{2}$ in $90 \%$ Helium for elemental carbon $(\mathrm{BC})$ determination. The carbon evolved with $\mathrm{O}_{2}$ present is corrected for pyrolized $\mathrm{OC}$ and then combined with the carbon detected during the $900^{\circ} \mathrm{C}$ (in helium) step to provide $\mathrm{BC}$ concentrations expected to agree with concentrations that would be obtained using the IMPROVE/ DRI TOR approach. The technique (referred to as MSC1) has precision of $\pm 10 \%$ and detection limit of $3 \mu \mathrm{g} \mathrm{C}$ per filter.

\subsection{Optical Measurements}

[18] As discussed earlier, the $\mathrm{k}$, estimated by comparison with $\mathrm{BC}$ determined by the thermal technique, varies in response to changes in the other particle-bound chemical constituents that accompany $\mathrm{BC}$ (e.g., $\mathrm{SO}_{4}^{2-}$, soil elements, $\mathrm{OC}$ ), as well as to differing scattering and absorption effects arising from filter loading and filter media. Thus, optical measurements are not expected to be an absolute measure of light absorption by airborne particles or even specifically of $\mathrm{BC}$ concentration. Despite this complication, these measurements are responsive to temporal variations in $\mathrm{BC}$ concentration at a given location.

\subsubsection{Aethalometer}

[19] The light absorption by the aerosol was measured with an AE-11 aethalometer (Magee Scientific) at all sites [Hansen et al., 1984]. The aethalometer measures the realtime attenuation of light transmitted through particles that accumulate on a quartz fiber filter. A vacuum pump draws air through the instrument so that the particles continuously accumulate on the filter while being illuminated by visible light (incandescent light source). The effective operational wavelength of aethalometer is $880 \mathrm{~nm}$. The light transmission is detected by two photo-diodes: one through the sample spot and the other through a blank (unsampled) portion of the filter called the reference spot. The change in attenuation is obtained as a function of time and has been found to relate to the $\mathrm{BC}$ concentration in $\left(\mathrm{g} / \mathrm{m}^{3}\right)$ as follows:

$$
\mathrm{BC}=\frac{-\mathrm{A} \cdot 100 \cdot \ln \left(\mathrm{l}_{2} / \mathrm{l}_{1}\right)}{\mathrm{k} \cdot \mathrm{Q}\left(\mathrm{t}_{2}-\mathrm{t}_{1}\right)}
$$

where $I_{1}$ and $I_{2}$ are the ratios of the intensities of the sample beam to the reference beam at times $t_{1}$ and $t_{2}$ (in seconds); $\mathrm{Q}\left(\mathrm{m}^{3} / \mathrm{s}\right)$ is the sample flow rate through the filter; $\mathrm{A}\left(\mathrm{m}^{2}\right)$ is the area of the exposed spot on the filter; and $\mathrm{k}$ is the specific attenuation coefficient. A recommended value for $\mathrm{k}$ of $19 \mathrm{~m}^{2} \mathrm{~g}^{-1}$, which is based upon calibrations during instrument development and theoretical calculations, is typically used. This accounts for absorption by BC and additional light attenuation assumed to be caused by the layering of particles or their close proximity on the filter, which induces multiple scattering. The detection limit of the aethalometer is dependent on the stability of the optics. Changes in the light intensity correspond to a noise level of $2 \mathrm{ng} \mathrm{m}^{-3}$. We have taken two times the standard deviation in the noise and report a detection limit of $4 \mathrm{ng} \mathrm{m}^{-3}$ for a 1 hour integration time.

\subsubsection{Particle Soot Absorption Photometer (PSAP)}

[20] The PSAP was run simultaneously with the aethalometer at all locations. It operates on a similar principle [Bond et al., 1999] to the aethalometer (i.e., equation (1)). However, the PSAP uses a $565 \mathrm{~nm}$ LED for its light source as compared to incandescent light source for aethalometer. The exposed spot diameter on which the sample is collected is $0.5 \mathrm{~cm}$ for the PSAP as compared to $1.1 \mathrm{~cm}$ for the 
aethalometer. The value determined for $\mathrm{k}$ for the PSAP is 10 $\mathrm{m}^{2} \mathrm{~g}^{-1}$ since the data processed by the instrument includes an empirical calibration that accounts for the enhancement in signal by the filter medium or the nonlinearities in the response of the detector as the filter is loaded. In contrast to the aethalometer, the limit of detection was restricted to the noise level, and for our setup (60s sampling time) it was determined to be $0.8 \mathrm{ng} \mathrm{m}^{-3}$ for a one minute integration time (two times the standard deviation). The flow and spot area correction was applied to the data.

\subsection{Site-Specific Attenuation Coefficients}

[21] As discussed earlier, the actual relationship between absorption and BC is expected to vary due to a number of factors. Thus, the $\mathrm{k}$ values of $19 \mathrm{~m}^{2} \mathrm{~g}^{-1}$ and $10 \mathrm{~m}^{2} \mathrm{~g}^{-1}$, used in the aethalometer and PSAP, respectively, may need to be adjusted. In reality, $\mathrm{k}$ could vary from sample to sample, but here we assume that location and season are two of the main factors. Thus, we compare the BC from the optical instruments and from the thermal technique by site and season. These results provide the information needed to adjust $\mathrm{k}$ in equation 1 , so that $\mathrm{BC}$ determined by aethalometer and PSAP agree with $\mathrm{BC}$ determined from the thermal technique.

[22] We refer to this adjusted $\mathrm{k}$ as the "site-specific k" (k (S.S.)):

$$
\mathrm{k}(\mathrm{S} . \mathrm{S} .)=\mathrm{k} \cdot \mathrm{b}_{\mathrm{aeth}} \text { or } \mathrm{k}(\mathrm{S} . \mathrm{S} .)=\mathrm{k} \cdot \mathrm{b}_{\mathrm{psap}}
$$

where $b_{\text {aeth }}$ and $b_{\text {psap }}$ are the correction factors which are equal to

$$
\frac{\mathrm{BC}_{\mathrm{aeth}}}{\mathrm{BC}_{\text {thermal }}} \text { and } \frac{\mathrm{BC}_{\mathrm{psap}}}{\mathrm{BC}_{\text {thermal }}} \text {, }
$$

respectively. Here $\mathrm{BC}_{\mathrm{aeth}}$ and $\mathrm{BC}_{\mathrm{psap}}$ are from equation (1) using $19 \mathrm{~m}^{2} \mathrm{~g}^{-1}$ or $10 \mathrm{~m}^{2} \mathrm{~g}^{-1}$, respectively.

\section{Results and Discussion}

\subsection{Thermal Analysis}

[23] Some Alert samples $(\mathrm{N}=12)$ were analyzed by both the 2-step and TOR methods to determine the relationship between the two techniques. Similarly, a set of common filters $(\mathrm{N}=8)$, taken at the Evans Avenue site, were analyzed by TOR and MSC1. Figure $2 \mathrm{a}$ shows that there is a high correlation $\left(\mathrm{r}^{2}=0.9\right)$, between the TOR and 2Step BC values but the 2-step approach results in higher concentrations (slope $=0.82$ ). TOR and MSC1 were also found to agree well $\left(\mathrm{r}^{2}=0.93\right)$ but with MSC1 concentrations slightly higher than BC determined by DRI using the IMPROVE TOR protocol (slope $=0.92$ ). This is shown in Figure 2b. Additional comparisons between the TOR temperature program and the MSC1 approach were conducted using the same instrument. Results in Figure $2 \mathrm{c}$ are consistent with the direct comparison with DRI-TOR. These comparisons suggest that $\mathrm{BC}$ determined from MSC1 and 2-Step can be expected to be similar with slightly smaller concentrations from TOR. While relatively small, these differences should be kept in mind when comparing thermal $\mathrm{BC}$ measurements and $\mathrm{k}$ estimates among sites.
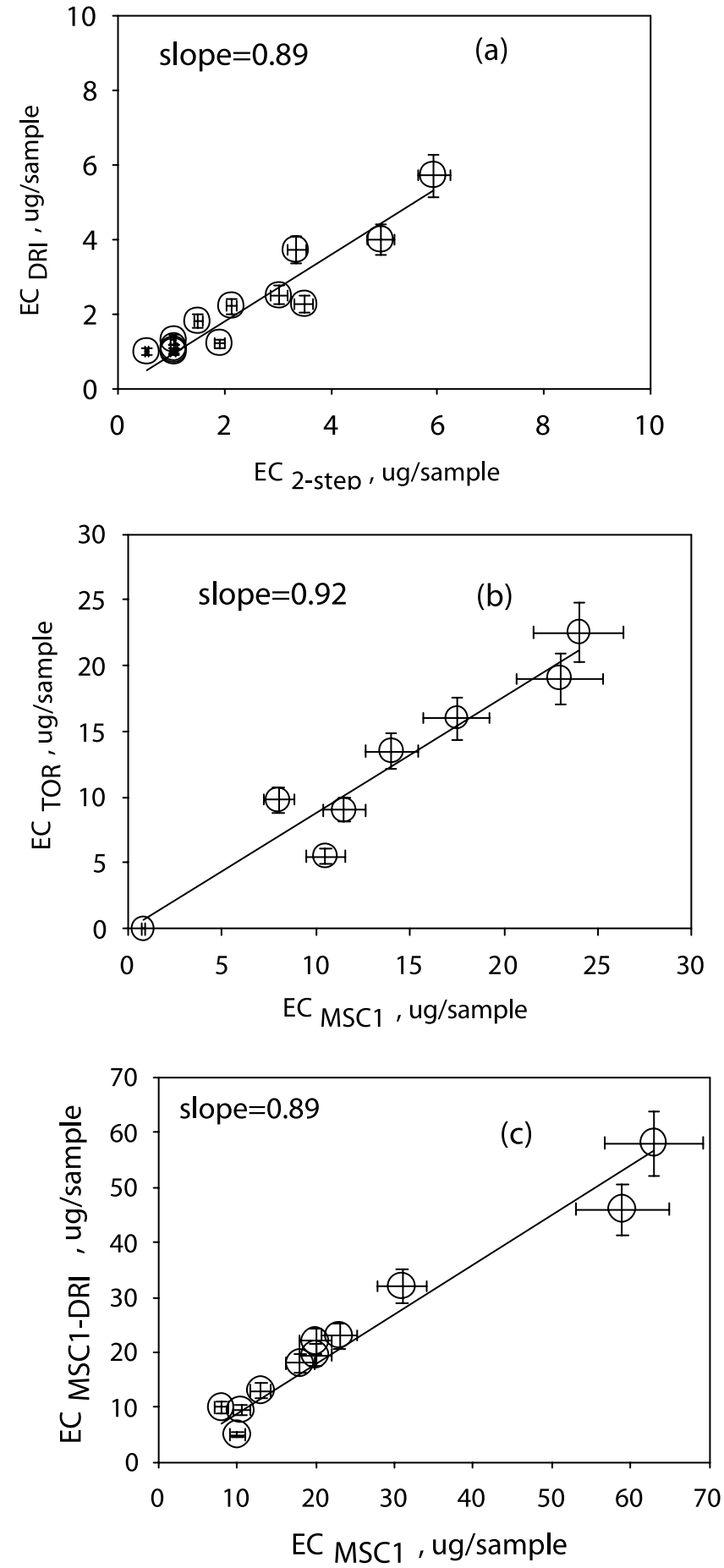

Figure 2. Intercomparison of the sample analysis result done by (a) the 2-step thermal technique [Cachier et al., 1989] and TOR technique [Chow et al., 1993] taken at Alert, (b) MSC1 versus TOR analysis of ambient filter samples, and (c) analyzed by MSC1 and MSC1 that mimics DRI temperature program.

[24] The $\mathrm{BC}$ and organic carbon (OC) concentrations obtained from the thermal techniques vary by more than one order of magnitude from one site to another, as shown in Table 2. The lowest BC and OC median values of 0.012 and $0.064 \mu \mathrm{g} \mathrm{m}^{-3}$ were measured at Alert. The highest BC 
Table 2. Minimum, Median, and Maximum BC and OC Concentrations and BC/TC Obtained by Two-Step Thermal, Total Optical Reflectance (TOR), and Total Optical Transmittance With Temperature Specifications of MSC1 (MSC1) Techniques

\begin{tabular}{|c|c|c|c|c|c|c|c|c|c|c|c|c|}
\hline \multirow[b]{2}{*}{ Location } & \multirow[b]{2}{*}{ Size Cut, $\mu \mathrm{m}$} & \multirow[b]{2}{*}{ Technique } & \multirow[b]{2}{*}{$\mathrm{N}$} & \multicolumn{3}{|c|}{$\mathrm{BC}_{\text {thermal }}$, ug $\mathrm{m}^{-3}$} & \multicolumn{3}{|c|}{$\mathrm{OC}, \mathrm{ug} \mathrm{m}^{-3}$} & \multicolumn{3}{|c|}{$\frac{\mathrm{BC}}{\mathrm{TC}}$} \\
\hline & & & & Min. & Max. & Med. & Min. & Max. & Med. & Min. & Max. & Med. \\
\hline \multicolumn{13}{|l|}{ Alert } \\
\hline Nov. 98-May 99 & - & 2-step & 13 & 0.021 & 0.129 & 0.087 & 0.03 & 0.17 & 0.064 & 0.21 & 0.77 & 0.51 \\
\hline June 99-Aug. 99 & - & 2-step & 7 & 0.006 & 0.016 & 0.012 & 0.05 & 0.074 & 0.067 & 0.08 & 0.18 & 0.15 \\
\hline Egbert July 1998 & 2.5 & TOR & 9 & 0.35 & 0.92 & 0.58 & 2.07 & 4.2 & 2.9 & 0.12 & 0.25 & 0.19 \\
\hline Downsview Jan. 2000 & 2.5 & TOR & 20 & 0.72 & 2.78 & 1.42 & 2.00 & 8.67 & 4.4 & 0.25 & 0.31 & 0.20 \\
\hline Evans Avenue March 2000 Near Highway & 2.5 & MSC1 & 16 & 0.81 & 4.15 & 1.95 & 2.00 & 9.5 & 4.6 & 0.24 & 0.37 & 0.30 \\
\hline Palmerston Road Aug. 2000 & 2.5 & MSC1 & 20 & 1.10 & 3.32 & 1.82 & 3.91 & 11.3 & 7.6 & 0.14 & 0.32 & 0.21 \\
\hline Winchester Aug. 2000 & 2.5 & MSC1 & 19 & 0.7 & 2.89 & 1.48 & 2.87 & 18.3 & 9.5 & 0.07 & 0.23 & 0.16 \\
\hline
\end{tabular}

and $\mathrm{OC}$ concentrations were measured at the urban locations; the median $\mathrm{BC}$ was $1.95 \mu \mathrm{g} \mathrm{m}^{-3}$ at Evans Avenue and the median $\mathrm{OC}$ was $18 \mu \mathrm{g} \mathrm{m}^{-3}$ at Winchester. However, the urban $\mathrm{BC}$ and $\mathrm{OC}$ concentrations were considerably smaller than the BC measurements of $14 \pm$ $7 \mu \mathrm{g} \mathrm{m}^{-3}$ and $\mathrm{OC}$ of $34.6 \pm 12 \mu \mathrm{g} \mathrm{m}^{-3}$ made at a location near a highway in Paris [Ruellan and Cachier, 2000]. This suggests that the levels in Canadian cities are relatively low.

\subsection{Determination of Site-Specific $k$ Values}

[25] For all sites, the relationships between $\mathrm{BC}$ obtained from the thermal and optical techniques are shown in Figure 3 for aethalometer and PSAP measurements. For
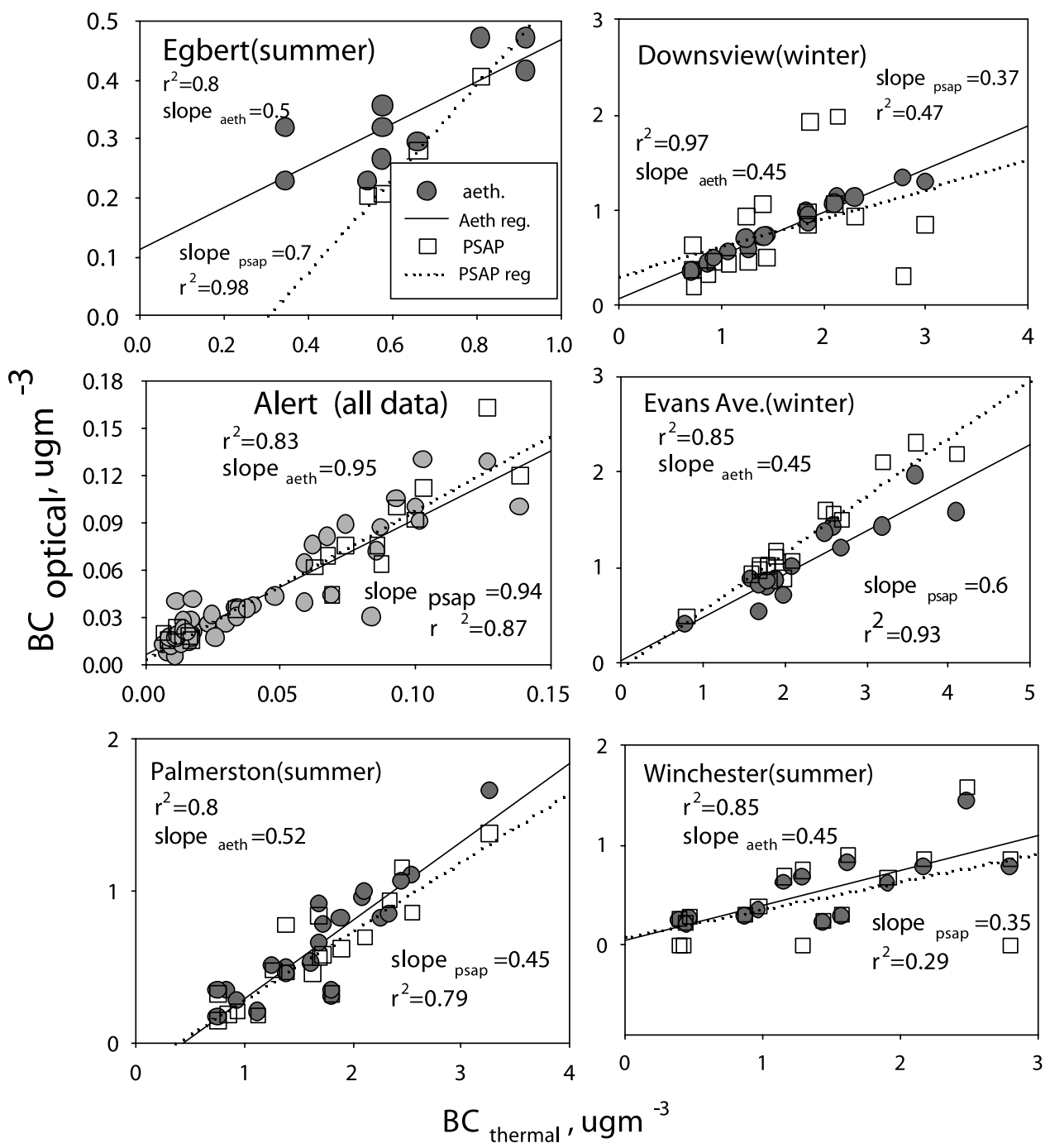

Figure 3. Relationships between $\mathrm{BC}$ concentrations obtained by thermal methods and light absorption instruments for the six sites: aethalometer (filled circles) and PSAP (open squares). BC was estimated by using $19 \mathrm{~m}^{2} \mathrm{~g}^{-1}$ for aethalometer and $10 \mathrm{~m}^{2} \mathrm{~g}^{-1}$ for the PSAP. 


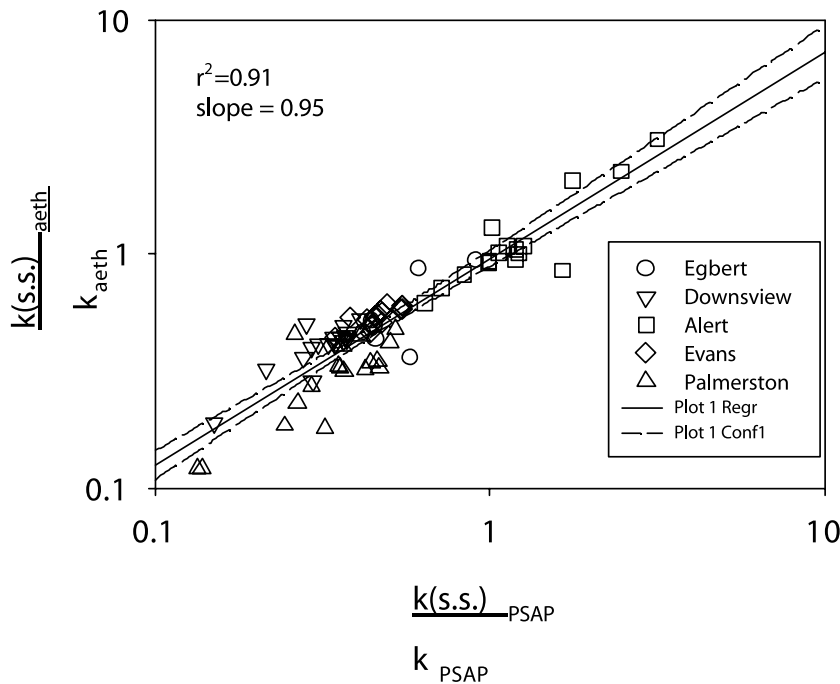

Figure 4. Relationship between the correction factors $b_{\text {aeth }}$ and $b_{\text {psap }}$ for the six sites as shown on a logarithmic scale. The dashed lines represent $95 \%$ confidence intervals. Symbols represent each measurement at different sites.

these figures the $\mathrm{k}$ values of $19 \mathrm{~m}^{2} \mathrm{~g}^{-1}$ for aethalometer and $10 \mathrm{~m}^{2} \mathrm{~g}^{-1}$ for PSAP were used to calculate the optically derived $\mathrm{BC}$ concentrations. Across all sites, good agreement was found (Figure $4, r^{2}=0.91$ and slope $=0.95$ ) between aethalometer and PSAP measurements $( \pm 10 \%)$, indicating that they respond similarly under a variety of situations.

[26] Overall at Alert, there is a reasonable correspondence between $\mathrm{BC}_{\text {aeth }}$ or $\mathrm{BC}_{\mathrm{psap}}$ and $\mathrm{BC}_{\text {thermal }}$ concentrations (for the aethalometer the slope $=0.95$ and $r^{2}=0.83$ ). This indicates that the values of $\mathrm{k}=19$ and $10 \mathrm{~m}^{2} \mathrm{~g}^{-1}$ are reasonable, which agrees with results from the Finnish Arctic [Ruellan and Cachier, 2000]. The slopes of the lines decrease from the remote/continental (median of the ratio $\mathrm{BC}_{\mathrm{opt}}$ to $\mathrm{BC}_{\text {thermal }}$ for aethalometer $\left.=0.99\right)$ to the suburban site (median of the ratio $\mathrm{BC}_{\mathrm{opt}}$ to $\mathrm{BC}_{\text {thermal }}$ for aethalometer $=0.34$ ) (see Table 3) suggesting $\mathrm{k}=19$ and $10 \mathrm{~m}^{2} \mathrm{~g}^{-1}$ does not lead to comparable $\mathrm{BC}_{\text {optical }}$ and $\mathrm{BC}_{\text {thermal }}$ at all locations. At Alert, the increase in the slope from winter to summer might suggest that some of the other aerosol constituents may also be light absorbing, such as soil dust. This has been shown in the measurements by Sirois and Barrie [1999], who from the samples collected from 19801995 showed that the soil dust contribution to the aerosol composition was increased by a factor of 2 during the summer under high wind conditions. At all the other sites, the optical technique underestimates $\mathrm{BC}$ with respect to the thermal technique, as indicated by slopes. Thus, in contrast to Alert in the summer, there is an absence of enhancement in the absorption found at the other sites, which could perhaps be due to different types of aerosol mixtures found at the two sites. The externally mixed aerosols may be playing a role in this observation in the cities where the emissions are fresh as compared to Alert, where it is aged and perhaps internally mixed, giving higher specific absorption coefficients. This was also seen in the other modeling exercises [Jacobson, 2001; Petzold et al., 1997].

[27] The differences in the slopes in Figure 3 show clearly that the relationship between the absorbance measured by the optical instruments and the amount of $\mathrm{BC}$ on the aerosol varies. Consequently, the $\mathrm{k}$ used to convert the aethalometer or PSAP absorption measurements to $\mathrm{BC}$ is variable. As shown in equation (2), site-specific coefficients $\mathrm{k}(\mathrm{S}$.S.) are determined from the ratio of $\mathrm{BC}_{\text {optical }}$ to $\mathrm{BC}_{\text {thermal. }}$. Values for the ratio and the resulting $\mathrm{k}(\mathrm{S} . \mathrm{S})$ each site and season are given in Table 3. Consistent with the slopes in Figure 3, the ratio of $\mathrm{BC}_{\text {aeth }}$ or $\mathrm{BC}_{\mathrm{PSAP}}$ to $\mathrm{BC}_{\text {thermal }}$ changes dramatically from Alert to the other sites. Table 3 shows that in Toronto, the $\mathrm{k}$ (S.S.) for the aethalometer is $9.5 \mathrm{~m}^{2} \mathrm{~g}^{-1}$ near a highway in winter and 7.6 and $7.5 \mathrm{~m}^{2} \mathrm{~g}^{-1}$ near two urban schools in summer. A summer time value of $8.7 \mathrm{~m}^{2} \mathrm{~g}^{-1}$ was determined for the rural location while the lowest value was $6.4 \mathrm{~m}^{2} \mathrm{~g}^{-1}$ observed during the winter at the suburban location of Downsview. The PSAP k(S.S.) values determined for all sites were about one half of what was obtained for the aethalometer. The $\mathrm{k}$ (S.S.) values ranged from 3.2 to $10.8 \mathrm{~m}^{2} \mathrm{~g}^{-1}$ across the sites.

[28] Our urban and rural aethalometer results are even lower than the $12 \mathrm{~m}^{2} \mathrm{~g}^{-1}$ determined for a small town near Paris [Liousse et al., 1993] and much lower than what was obtained in Paris near a highway where $19 \mathrm{~m}^{2} \mathrm{~g}^{-1}$ was observed [Ruellan and Cachier, 2000]. Note that the 2-step thermal method was used to measure $\mathrm{BC}$ at Alert and the Paris-area locations while TOR or MSC1 was used elsewhere. However, Figure 2 indicates that the differences in Figure 3 and Table 3 cannot be a result of this change in thermal analysis techniques. Therefore, we suggest that the overall aerosol composition and perhaps morphology is leading to the differences. For example, there is a high proportion of diesel traffic in France (36\% by volume) (International automobile statistics) compared to Canada ( $8.0 \%$ by volume) (Environment Canada-Pollution Data Branch), and the aerosol absorptive properties in Table 3

Table 3. Minimum, Maximum, and Median Ratios of the Light Absorption BC to Thermal $\mathrm{BC}^{\mathrm{a}}$

\begin{tabular}{|c|c|c|c|c|c|c|c|c|c|c|c|c|}
\hline \multirow[b]{2}{*}{ Location } & \multicolumn{3}{|c|}{$\frac{\mathrm{BC}_{\text {acthal }}}{\mathrm{BC}_{\text {thermal }}}$} & \multicolumn{3}{|c|}{$\frac{\mathrm{BC}_{\text {psap }}}{\mathrm{BC}_{\text {thermal }}}$} & \multicolumn{3}{|c|}{$\begin{array}{l}\mathrm{k}(\mathrm{S} . \mathrm{S} .), \mathrm{m}^{2} \mathrm{~g}^{-1} \\
\text { Aethalometer }\end{array}$} & \multicolumn{3}{|c|}{$\mathrm{k}($ S.S. $), \mathrm{m}^{2} \mathrm{~g}^{-1}$ PSAP } \\
\hline & Min. & Max. & Med. & Min. & Max. & Med. & Min. & Max. & Med. & Min. & Max. & Med. \\
\hline \multicolumn{13}{|l|}{ Alert } \\
\hline winter & 0.6 & 1.6 & 1.0 & 0.6 & 1.3 & 1.0 & 11.4 & 29.8 & 18.8 & 6.3 & 13.0 & 10.2 \\
\hline summer & 1.4 & 2.3 & 1.5 & 0.4 & 1.9 & 1.2 & 28.3 & 43.8 & 28.3 & 3.8 & 19.0 & 11.6 \\
\hline Egbert summer & 0.2 & 0.6 & 0.5 & 0.4 & 0.5 & 0.4 & 4.6 & 11.6 & 8.7 & 3.5 & 5.0 & 4.3 \\
\hline Downsview winter & 0.2 & 0.5 & 0.3 & 0.1 & 1.2 & 0.5 & 2.9 & 8.5 & 6.4 & 1.5 & 4.5 & 3.4 \\
\hline Evans Avenue winter & 0.3 & 0.5 & 0.5 & 0.4 & 0.7 & 0.6 & 6.4 & 10.3 & 9.5 & 3.4 & 5.4 & 5.0 \\
\hline Palmerston Road Summer & 0.1 & 0.5 & 0.4 & 0.1 & 0.5 & 0.3 & 2.4 & 10.5 & 7.5 & 1.3 & 5.1 & 3.6 \\
\hline Winchester Summer & 0.1 & 0.6 & 0.3 & 0.1 & 0.6 & 0.3 & 2.3 & 11.1 & 7.5 & 1.2 & 5.8 & 3.2 \\
\hline
\end{tabular}

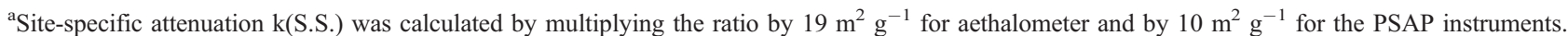



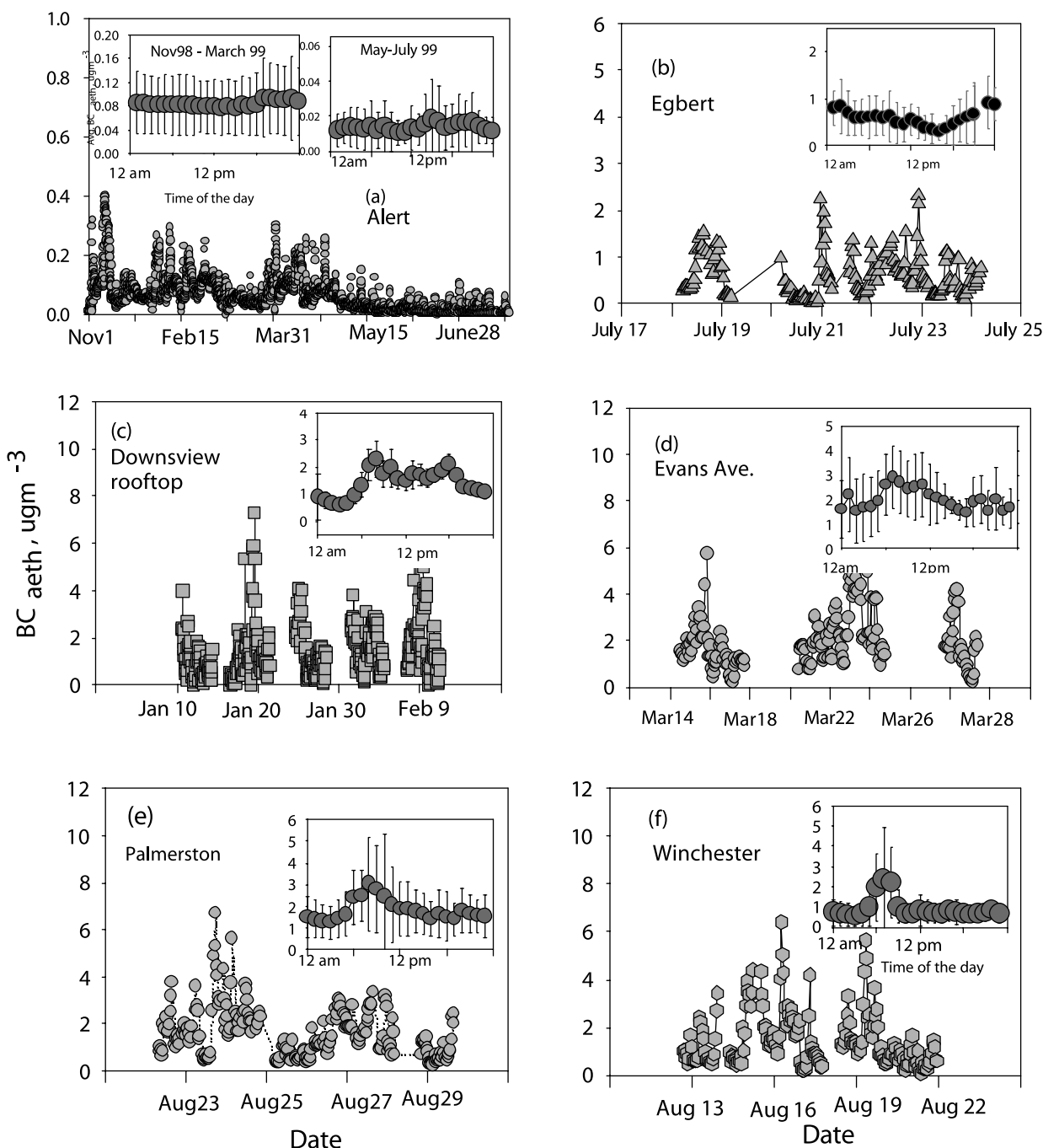

Figure 5. Hourly integrated black carbon concentrations measured by aethalometer at six Canadian sites. Diurnal variations in black carbon concentrations (means and $1 \mathrm{sd}$ ) are shown in the top right insert for each site. The site-specific attenuation k(S.S.) were used for each site.

compared to Liousse et al. [1993] might reflect this difference. Table 3 indicates that in general, the characteristics of the aerosol differ between Alert and S. Ontario and the Paris area. There are also, not surprisingly, differences occurring in each region from measurement to measurement. A measure of this behavior is given by the $r^{2}$ values in Figure 3. At all locations, there is a scatter in the relationships. As with the differences between regions, this may be partially due to variations in the particle composition caused by differences in the sources and processes contributing to the air mass. For instance, at Alert, there is more scatter in the data for the samples taken in the summer than during winter $\left(\mathrm{r}_{\text {summer }}^{2}=0.5, \mathrm{~N}=14\right.$ and $\mathrm{r}_{\text {winter }}^{2}=0.9, \mathrm{~N}=28$. More $\mathrm{BC}$ samples (September 1999 to June 2000) were included in the comparison at Alert as compared to what is stated in Table 2). Air masses from distant source regions are more prevalent during the wintertime, and the aerosols they contain are aged, well mixed (internally mixed) and less variable. In contrast, during the summer, the air mass is more often influenced by the locally emitted/produced aerosols (more likely to be from crustal, marine and biogenic sources with less influence from combustion). The very low summertime concentrations, which are close to the detection limit, lead to more uncertainty and more scatter as shown in Figure 3. It should be noted that in Figure 3 and Table 3, we included more Alert BC measurements (until September 2000) than listed in Table 2 to gain more confidence in the relationship between the two parameters. The least amount of scatter in the individual k(S.S.) values was in the winter at Downsview. This site is close to a major road and during the measurement period, the relative influence of this source and others apparently remained quite stable. Comparatively, Egbert, Winchester and Palmerston, during the summer, were influenced by a more variable mixture of sources. An increase in organic fraction on the carbonaceous aerosol could affect both optical techniques by changing the optical properties of the aerosol and it could also complicate the separation of $\mathrm{BC}$ and $\mathrm{OC}$ in the thermal analysis.

[29] To summarize the results and compare the aethalometer and PSAP, the correction factor, $b$, was determined by taking ratios of $\mathrm{k}\left(\mathrm{S} . \mathrm{S}\right.$.) to $\mathrm{k}\left(19 \mathrm{~m}^{2} \mathrm{~g}^{-1}\right.$ for aethalometer 

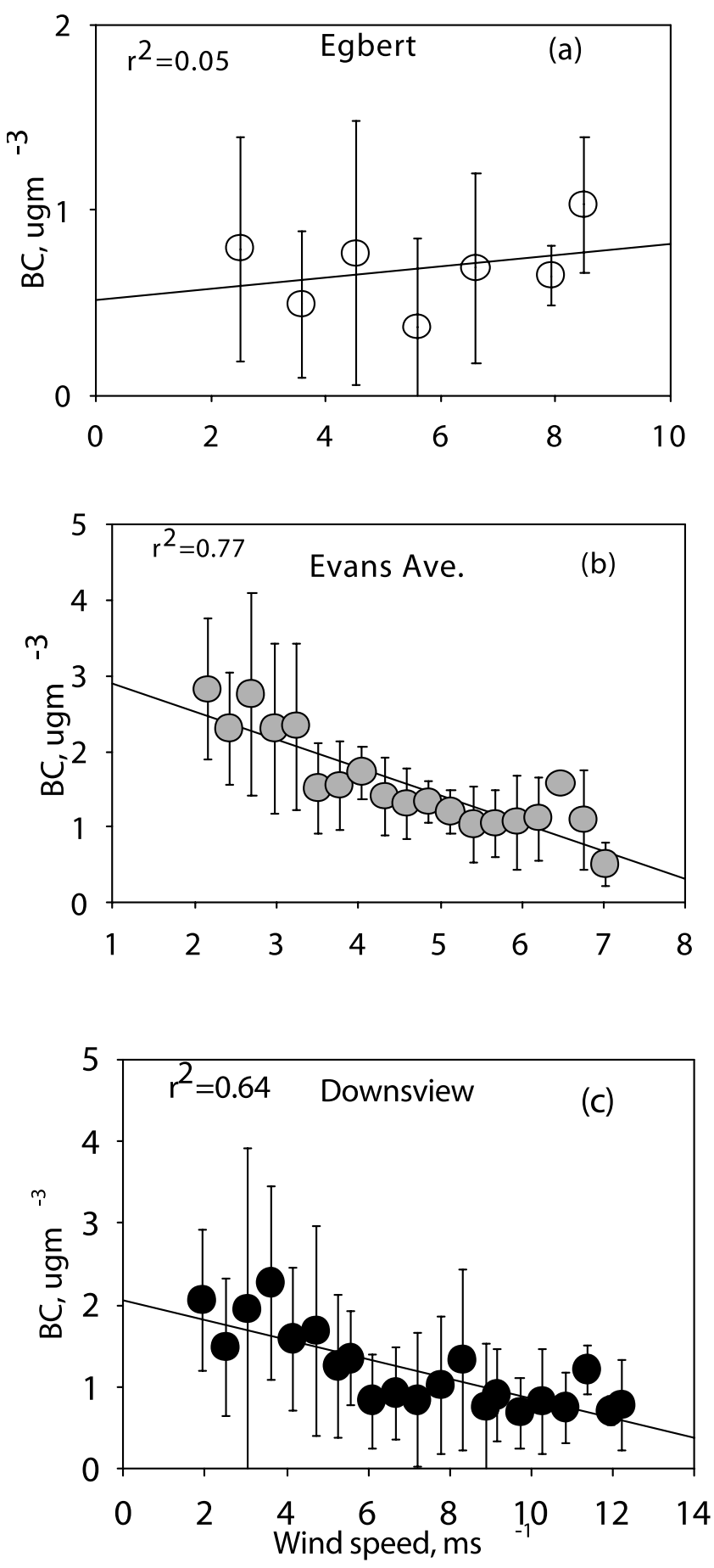

Figure 6. Influence of wind speeds on BC concentrations measured by aethalometer as a function of distance from the $\mathrm{BC}$ source regions as shown in Figure 6a away from the source region and in Figures $6 \mathrm{~b}$ and $6 \mathrm{c}$ closer to the source region.

and $10 \mathrm{~m}^{2} \mathrm{~g}^{-1}$ for the PSAP). Figure 4 shows the relationship between the correction factor $b_{\text {aeth }}$ and $b_{\text {PSAP }}$ for all sites and measurements. Although these results show that the direct relationship between the $\mathrm{BC}$ derived from optical measurements and thermal techniques is variable, the high time resolution optical instruments provide useful informa- tion. Furthermore, the optical measurements can be adjusted using data in Table 3 to provide a good relative measure of $\mathrm{BC}$ for each site.

\subsection{Analysis of the Aethalometer Measurements}

[30] Time series of hourly average BC concentrations measured by the aethalometer using the site-specific attenuation k (S.S.) are shown in Figure 5 for the six locations. As shown in Table 2, the BC concentrations derived from aethalometer were smallest at Alert, consistent with its large distance from the North American, European and Asian source regions. During the time period shown (winter), Alert is often influenced by air from Eurasia due to long-range transport arising from flow around four semi-permanent pressure systems [Maxwell, 1980]. The Alert wintertime concentrations of BC varied from $0.01 \mu \mathrm{g} \mathrm{m}^{-3}$ to $0.4 \mu \mathrm{g} \mathrm{m}^{-3}$. The standard deviation in the data, during the six month period, is large, suggesting that the extent to which distant sources impact on the site varies considerably. The mean $\mathrm{BC}$ concentrations during the winter (Arctic haze period) are a factor of 4 higher than the summer BC concentrations. In addition, there is some diurnal variability in the $\mathrm{BC}$ concentrations during the summer, while no such pattern occurred in the winter. The dynamics of the boundary layer during the summer, which is complicated because of $24 \mathrm{hrs}$ of sunlight and the proximity of the ocean, could contribute to this variation.

[31] The other four sites are relatively close to large BC source regions such as industrial and automobile emissions and biomass burning. Egbert (Figure 5b), is rural but is frequently affected by anthropogenic sources because of its proximity to heavily populated areas. The concentration of $\mathrm{BC}$ ranged between 0.06 to $2 \mu \mathrm{g} \mathrm{m}^{-3}$. Similar to Alert, the temporal variation at Egbert reflects synoptic scale influence on the transport of $\mathrm{BC}$ containing air masses with elevated concentrations lasting 2 to 3 days. During the Egbert study, there was a tendency for lower concentrations during the daytime. While there are too few data to conclude that this represents a typical pattern, the observed behavior could have been due to mixing and boundary layer height, which are reduced at night possibly leading to enhancement of local sources or more concentrated urban plumes.

[32] At the urban sites there was a distinct increase in BC concentration during morning rush hour peaking between 8:00-9:00 (EST) and to a lesser degree between 17:00 to 19:00. The sharp morning peaks were mainly driven by vehicular emissions and the boundary layer dynamics. The reason the evening peak is more pronounced at Downsview is because the measurements were from the winter when mixing height remains smaller in the day and decrease sooner in the afternoon/evening. The mean BC concentrations ranged from about $0-6 \mu \mathrm{g} \mathrm{m}^{-3}$ at all urban locations. The fact that the residential sites experienced a similar diurnal pattern and concentration compared to Evans Avenue indicates that the influence of traffic spreads relatively far from the major roadways.

[33] The influence of wind speed on the BC concentrations is shown in Figure 6. Only Egbert, Evans Avenue and Downsview are shown since they exemplify a range of distances from likely $\mathrm{BC}$ sources. There is a clear negative correlation between $\mathrm{BC}$ and wind speed at Evans Avenue 


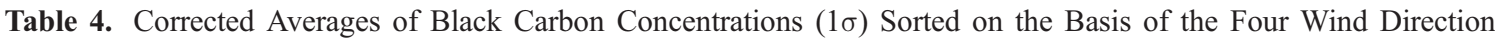
Sectors

\begin{tabular}{|c|c|c|c|c|c|}
\hline & \multicolumn{5}{|c|}{ Wind Sectors } \\
\hline & $1 \mathrm{NE}\left(0^{\circ}-90^{\circ}\right)$ & $2 \operatorname{SE}\left(90^{\circ}-180^{\circ}\right)$ & $3 \mathrm{SW}\left(180^{\circ}-270^{\circ}\right)$ & $4 \mathrm{NW}\left(270^{\circ}-360^{\circ}\right)$ & Average of All Directions \\
\hline \multicolumn{6}{|l|}{ Egbert } \\
\hline Average & $0.95(0.53)$ & $0.86(0.44)$ & $1.15(0.71)$ & $0.68(0.65)$ & $0.75(0.52)$ \\
\hline $\mathrm{N}$ & 15 & 4 & 84 & 101 & \\
\hline \multicolumn{6}{|c|}{ Palmerston Road } \\
\hline Average & $1.75(1.08)$ & $1.54(0.99)$ & $1.9(1.4)$ & $1.59(0.91)$ & $1.69(1.09)$ \\
\hline $\mathrm{N}$ & 44 & 62 & 50 & 36 & \\
\hline \multicolumn{6}{|c|}{ Alert (Winter) } \\
\hline Average & $0.11(0.078)$ & $0.083(0.043)$ & $0.078(0.053)$ & $0.093(0.056)$ & $0.086(0.05)$ \\
\hline $\mathrm{N}^{\mathrm{a}}$ & 85 & 227 & 1379 & 368 & \\
\hline \multicolumn{6}{|c|}{ Alert (Summer) } \\
\hline Average & $0.024(0.039)$ & $0.020(0.045)$ & $0.034(0.054)$ & $0.043(0.036)$ & $0.019(0.016)$ \\
\hline $\mathrm{N}^{\mathrm{a}}$ & 134 & 171 & 669 & 475 & \\
\hline \multicolumn{6}{|c|}{ Winchester Road } \\
\hline Average & $0.86(0.96)$ & $0.91(0.86)$ & $1.97(2.43)$ & $1.29(0.94)$ & $1.32(1.32)$ \\
\hline $\mathrm{N}$ & 18 & 24 & 26 & 72 & \\
\hline \multicolumn{6}{|l|}{ Downsview } \\
\hline Average & $1.16(0.99)$ & $1.94(0.95)$ & $2.04(1.33)$ & $0.95(0.81)$ & $1.24(1.07)$ \\
\hline $\mathrm{N}$ & 64 & 16 & 67 & 216 & \\
\hline \multicolumn{6}{|c|}{ Evans Avenue } \\
\hline Average & $1.65(0.94)$ & $2.31(1.13)$ & $1.75(0.52)$ & $2.13(1.35)$ & $1.97(1.13)$ \\
\hline $\mathrm{N}$ & 63 & 46 & 27 & 76 & \\
\hline
\end{tabular}

${ }^{\mathrm{a}} \mathrm{N}$ is the number of measurements pertaining to each sector. For this analysis, we used BC concentrations data for 1999 and 2000.

and Downsview whereas there is not a clear pattern at Egbert. These differences reflect proximity to sources. At Evans and Downsview, low wind speeds lead to much less dispersion of $\mathrm{BC}$, so the nearby traffic emissions remain more concentrated around the site. Conversely, since daily traffic density was relatively constant through the period, higher wind speeds have a dilution effect on BC. The lack of a relationship at Egbert suggests that the BC originates from more distant sources, as opposed to local source emissions, which build up when winds are light. This conclusion suggests that the higher nighttime levels at Egbert noted above were probably results of lower mixing heights and more frequent urban plumes at night since the predominant wind direction at night was usually from the SW.

[34] Table 4 illustrates the $\mathrm{BC}$ dependence on wind direction. The data for all sites were segregated into 4 different sectors; $0-90^{\circ}$ as NE, $90-180^{\circ}$ as SE, $180-270^{\circ}$ as SW and $270-360^{\circ}$ as NW. BC in the air mass at Alert, in the winter, is well mixed due to large distance between the source and site regions. Despite this, higher concentrations in $\mathrm{BC}$ were found in the $\mathrm{NE}$ and $\mathrm{NW}$ wind direction quadrants, suggesting higher emissions from the European sector. The frequency of the measurements was found to be highest in the SW sector, which had the lowest BC concentrations. During the summertime, the winds from the SE and SW sectors brought in higher BC concentrations and again the highest frequency of measurements was from the $\mathrm{SW}$ sector. This dependence of $\mathrm{BC}$ on direction suggests a greater contribution from the North American BC sources.

[35] At Egbert, higher concentrations of $\mathrm{BC}$ were associated with the SW sector bringing in dirtier air masses from the nearby cities. Lower BC occurred with NW winds. We have less confidence in the $\mathrm{BC}$ concentrations for the other wind-sectors at Egbert because of the smaller number of data points. The patterns at Evans and Winchester also reflect the distribution of sources around the site. At Evans, higher concentrations were found in the SE and NW sectors. In the SE quadrant there is a highway on/off ramp and a stoplight, both of which have a strong impact on the driving cycle of diesel trucks. The greatest traffic density, overall around Evans is in the NW quadrant due to the Gardiner and 427 highways (see Figure 1). At Winchester, a factor of 2 higher $\mathrm{BC}$ concentrations were found for $\mathrm{SW}$ and NW winds, suggesting the greatest traffic density in these directions.

[36] At Downsview, the SW and SE quadrants had about a factor of 2 higher BC concentrations compared to NW and NE. This is somewhat consistent with the N-S roadway just west of the site but also reflects the fact that the site is on the north edge of Toronto. BC concentrations observed in the other two sectors $\left(1 \mathrm{\mu g} \mathrm{m}^{-3}\right)$ are likely more representative of the overall levels within the urban area. In contrast to the other urban sites, the differences in the $\mathrm{BC}$ concentrations among all quadrants at Palmerston were relatively small. This suggests no strong directional bias in the $\mathrm{BC}$ sources relative to the site.

\section{Conclusions}

[37] The aethalometer and PSAP instruments agree with each other and underestimate $\mathrm{BC}$ as determined by thermal analysis techniques, by as much as $76 \%$ at all sites except for Alert. The k(S.S) values of $18.8 \mathrm{~m}^{2} \mathrm{~g}^{-1}$ and $10 \mathrm{~m}^{2} \mathrm{~g}^{-1}$ determined for the aethalometer and PSAP instruments operated at Alert agree well with the manufacturer's nominal. Thus, if the objective of the optical measurement is to report $\mathrm{BC}$ values that are consistent with the filter-based thermal analysis techniques, then the specific attenuation, $\mathrm{k}$, must be fine-tuned to fit the conditions and types of aerosols present at the location of measurements.

[38] The site to site and sample to sample variability in the ratio of $\mathrm{BC}_{\text {ath }}$ to $\mathrm{BC}_{\text {thermal }}, \mathrm{k}(\mathrm{S} . \mathrm{S}$.$) , reflects on the$ composition of the aerosol. The magnitude of the ratio indicates that there are other light-absorbing species (e.g., 
dust particles) present in aerosol phase and size distribution effects at Alert in the summer as compared to populated areas. The extent to which this phenomenon occurs when the aerosols are present in the atmosphere, as opposed to collected on an aethalometer or PSAP filter, needs to be examined. Similar atmospheric behavior would indicate that the full chemical make-up and degree of external versus internal mixing needs to be accounted for before effects on the radiative balance can be determined.

[39] Analysis of the time series of aethalometer and PSAP, BC measurements showed a distinct diurnal variation at all sites except for Alert during the winter and Egbert. This is due to the dynamics of the boundary layer and variation in the source strength (i.e., morning and evening rush hour). Wind speeds have an affect on concentration at sites closer to sources, with lighter winds leading to higher levels. The time resolution of aethalometer and PSAP measurements also helps to reveal the location of significant sources and to determine typical urban background $\mathrm{BC}$ concentrations relative to concentrations impacted upon by local sources.

\section{References}

Andreae, M. O., The dark side of aerosols, Nature, 409(6821), 671-672, 2001.

Ballach, J., R. Hizenberger, E. Schultz, and W. Jaeschke, Development of an improved optical transmission technique for black carbon (BC) analysis, Atmos. Environ., 35, 2089-2100, 2001.

Barrie, L. A., and U. Platt, Arctic tropospheric chemistry: An overview, Tellus, Ser. B, 49(5), 450-454, 1997.

Birch, M. E., and R. A. Cary, Elemental carbon-based method for monitoring occupational exposures to particulate diesel exhaust, Aerosol Sci. Technol., 25(3), 221-241, 1996.

Bond, T. C., T. L. Anderson, and D. Campbell, Calibration and intercomparison of filter-based measurements of visible light absorption by aerosols, Aerosol Sci. Technol., 30(6), 582-600, 1999.

Cachier, H., M. Bremond, and P. Buat-Menard, Determination of atmospheric soot carbon with a simple thermal method, Tellus, Ser. B, 41(3), 379-390, 1989

Chen, L. W., B. G. Doddridge, R. R. Dickerson, J. C. Chow, P. K. Mueller, J. Quinn, and W. A. Butler, Seasonal variations in elemental carbon aerosol, carbon monoxide, and sulfur dioxide: Implications for sources, Geophys. Res. Lett., 28(9), 1711-1714, 2001.

Chow, J. C., J. G. Watson, L. C. Pritchett, W. R. Pierson, C. A. Frazier, and R. G. Purcell, The DRI Thermal/Optical Reflectance carbon analysis system: Description, evaluation and applications in U. S. studies, Atmos. Environ., Part A, 27, 1185-1201, 1993.

Chow, J. C., J. G. Watson, D. Crow, D. H. Lowenthal, and T. Merrifield, Comparison of IMPROVE and NIOSH carbon measurements, Aerosol Sci. Technol., 34(1), 23-24, 2001.

De Santis, F., and I. Allegrini, Heterogeneous reactions of $\mathrm{SO}_{2}$ and $\mathrm{NO}_{2}$ on carbonaceous surfaces, Atmos. Environ., Part A, 26, 3061-3064, 1992.

Edwards, J. D., J. A. Ogren, R. E. Weiss, and R. J. Charlson, Particulate air pollutants: A comparison of British "smoke" with optical absorption coefficient and elemental carbon concentration, Atmos. Environ., 17, 2337-2341, 1983.
Fung, K. K., Particulate carbon speciation by $\mathrm{MnO}_{2}$ oxidation, Aerosol Sci. Technol., 12(1), 122-127, 1990.

Hansen, A. D. A., H. Rosen, and T. Novokov, The aethalometer: An instrument for the real-time measurement of optical absorption by aerosol particles, Sci. Total Environ., 36, 191-196, 1984

Horvath, H., Experimental calibration for aerosol light absorption measurements using the integrating plate method: Summary of the data, J. Aerosol Sci., 28(7), 1149-1161, 1997

Jacobson, M. Z., Strong radiative heating due to the mixing state of the black carbon in atmospheric aerosols, Nature, 409(6821), 695-697, 2001.

Keeler, G. J., The sources of aerosol elemental carbon at Allegheny Mountain, Atmos. Environ., Part A, 24, 2795-2805, 1990

Lavanchy, V. W. H., H. W. Gäggeler, S. Nyeki, and U. Baltensperger, Elemental carbon (EC) and black carbon (BC) measurements with a thermal method and an aethalometer at the high-alpine research station Jungfraujoch, Atmos. Environ., 33, 2759-2769, 1999.

Liousse, C., H. Cachier, and S. G. Jennings, Optical and thermal measurements of black carbon aerosol content in different environments: Variation of the specific attenuation cross-section, sigma( $\sigma)$, Atmos. Environ., Part A, 27, 1203-1211, 1993.

Maxwell, J. B., The Climate of the Canadian Arctic Islands and Adjacent Waters, vol. 1, Climatol. Stud. 30, 531 pp., Environ. Can., Downsview, Ont., 1980.

Novakov, T., and C. E. Corrigan, Thermal characterization of biomass smoke particles, Mikrochim. Acta, 117(1-2), 157-166, 1995.

Petzold, A., and R. Niessner, Method comparison study on soot-selective techniques, Mikrochim. Acta, 117, 215-237, 1995.

Petzold, A., C. Kopp, and R. Niessner, The dependence of the specific attenuation cross-section on black carbon mass fraction and particle size, Atmos. Environ., 31, 661-672, 1997.

Ruellan, S., and H. Cachier, Characterization of fresh particulate vehicular exhaust near a Paris high flow road, Atmos. Environ., 35, 453-468, 2000.

Schmid, H., et al., Results of the "carbon conference" international aerosol carbon round robin test stage I, Atmos. Environ., 35, 2111-2121, 2001.

Sirois, A., and L. A. Barrie, Arctic lower tropospheric aerosol trend and composition at Alert, Canada: 1980-1995, J. Geophys. Res., 104(D9), 11,599-11,618, 1999

Smith, D. M., M. S. Akhter, J. A. Jassim, C. A. Sergides, W. F. Welch, and A. R. Chughtai, Studies of the structure and reactivity of soot, Aerosol Sci. Technol., 10, 311-325, 1989

Tohno, S., and R. Hitzenberger, Comparison of ambient carbon particulate monitor and filter sampling for black carbon measurement, J. Aerosol Sci., 31, suppl. 1, S315-S316, 2000.

Waggoner, A. P., R. E. Weiss, N. C. Ahlquist, D. S. Covert, S. Will, and R. J. Charlson, Optical characteristics of atmospheric aerosols, Atmos. Environ., 15, 1891-1909, 1981.

Worthy, D. E. J., N. B. A. Trivett, and C. Blanchette, Canadian Baseline Program summary of progress to 1998, pp. 1-11, Environ. Can., Downsview, Ont., 1999.

Yu, J. Z., J. Xu, and H. Yang, Charring characteristics of atmospheric organic particulate matter in thermal analysis, Environ. Sci. Technol., 36(4), 754-761, 2002.

J. R. Brook, A. Gaudenzi, G. Lu, and S. Sharma, Meteorological Service of Canada, 4905 Dufferin Street, Toronto, Ontario, Canada M3H 5T4. (sangeeta.sharma@ec.gc.ca)

H. Cachier, LSCE/CFR, Laboratoire Mixte CEA-CNRS, Domaine du CNRS, Bat 12 Avenue de la Terrasse, 91 198-Gif sur Yvette Cedex, France. J. Chow, Desert Research Institute, 2215 Raggio Parkway, Reno, NV 89512, USA. 